\title{
Competitiveness of the Serbian Economy Through the Prism of Tax Incentives for Foreign Investors
}

\author{
Darko Marjanović $\mathbf{1}^{*}$ \\ ${ }^{1}$ Instituite of Economic Sciences, Belgrade, Serbia
}

\begin{abstract}
In order to make Serbia the most attractive investment destination in relation to countries in the region, special attention should be paid to the current tax incentives granted to foreign investors. Hence, the aim of this paper is to find the opinion and attitudes of foreign investors in the relevant research and analysis regarding the importance of tax relief for their investment in Serbia. Tax incentives are one of the most important tax instruments that can play a decisive role on foreign investors when choosing an investment location, and therefore to increase the competitiveness of the Serbian economy. In this paper, special attention will be given to tax incentives in certain areas for the business of foreign investors, depending on the way foreign investors enter the Serbian market. The methodology of empirical research in this paper is based on a quantitative approach to the collection of primary data through the survey of relevant subjects, the comparison of collected data, and the analysis of the causality of the investigated phenomena. On the basis of the obtained results it can be concluded that the greatest influence on the investor when making a decision on investing in Serbia is tax incentives in corporate income tax.
\end{abstract}

Key words: tax incentives, competitiveness, FDI, investors

JEL Classification: E62, H20

\section{INTRODUCTION}

Fiscal policy is a very powerful instrument for attracting foreign investment. During the 1990s, Central Europe countries used "tax breaks" and other fiscal incentives for this purpose. As a result, there has been an increase in the volume and quantity of capital inflows, all of which has led to the growth of the economies of these countries, and thus to increasing their competitiveness. As it is known that taxpayers seek to lower their tax liability to the lowest possible level, they are interested in using the various tax incentives provided by the state in the process of tax competition. There is a conflict between the interests of the state, on the one hand, to attract as much investment (lower tax burden) and, on the other hand, to raise as much funds to finance public functions (higher tax burden).

With the increasing increase in the free movement of capital in the world market, the states have come in a position to compete with one another for the affection of business entities, with the aim of attracting as much investment as possible on their territory. As one of the most important forms of international capital movements, FDI play an important role in any economic system (Musabegović et al., 2015). A generally supported attitude is that fiscal policy is a very powerful instrument for attracting investment, that is, tax competition is one of the most important indicators of overall competitiveness. For this reason, it is very important for all

\footnotetext{
*E-mail: darko.marjanovic@ien.bg.ac.rs
} 
countries to offer attractive conditions to investors, first of all through favorable tax treatment, and in this way try to secure as high a capital inflow. Under special tax treatment, it is understood, above all, to expand the tax base and/or reduce the tax rate of the corporate income tax. In creating tax policy, it is attempting to reduce the tax burden, which should contribute to entering new investments, i.e. preventing their outflow. The result of all this should be an increase in the volume and quantity of capital inflows, the growth and development of the economy, and the increase in competitiveness. Therefore, one state's goal is to provide a favorable ambience for investors, which are reflected in providing better conditions than competitive countries, and thus create an advantage that will lead to new investments. However, in this situation, usually it happens "race to the bottom", when individual countries, in order to be attractive to investors, compete in lowering tax rates by creating an attractive tax environment.

One of the instruments for increasing investments also relates to a stimulating tax environment in which the largest impact on companies and potential investors has a tax on profits, or tax incentives in the corporate income tax system (Domazet \& Marjanović, 2018). Tax on profit is one of the most important tax instruments for stimulating economic activity in the domestic environment, but also for attracting the necessary foreign capital. Different tax incentives in the profit tax system have become a key determinant of tax competition in attracting foreign capital. Nowadays, the most successful ones are those countries that have undoubtedly realized a significant inflow of foreign capital precisely by providing investors with a preferential tax treatment with a series of reliefs, primarily in the corporate income tax system, but also providing the necessary economic and social conditions.

One of the key factors in starting the process of improving the competitiveness of the Serbian economy is, of course, also the fiscal system and fiscal policy. It is precisely for this reason that it is necessary to set the institutional foundations of the fiscal system, while simultaneously increasing the efficiency of the tax administration and creating a transparent control of public finances. In addition to institutional arrangements, for the competitiveness of the Serbian economy it is certainly necessary to make changes within the fiscal system that should be one of the factors of economic development (Domazet \& Marjanović, 2017).

\section{LITERATURE REVIEW}

Competition is created in moments when individuals and companies get the choice. The greatest satisfaction of individuals and companies is the aspiration for a lesser degree of jurisdiction, i.e. the state in which individuals and companies conduct business (Keen \& Konrad, 2012). The main reasons explaining the phenomenon of tax competition are increasing international trade flows and investments, increasing labor mobility between countries, and the ever-faster transfer of technology. In such an economic environment it is very difficult to maintain high tax rates. Freedom of movement of capital creates a kind of pressure on the state to reduce the tax rate, above all the profit tax, in order to maintain its attractiveness (Davies \& Voget, 2008). Tax competition is fully in line with the fundamental tax reform. Among other things, the tax reform objective is a system with low tax rates in response to productive behavior, as well as a system in which income is taxed only once. Tax competition promotes tax reform by helping to reduce marginal tax rates as well as eliminating double taxation of revenues that has been saved and invested (Paraušić et al., 2017). When tax rates are in question, the most obvious negative effect of tax competition is a sort of "race to the bottom", precisely because countries and/or regions compete in reducing tax rates to create equally attractive business environments that would be favorable for foreign investments. Tax competition, by its impact on lowering tax rates, often involves lowering the tax base for tax collection, and hence the local government or government of the country has fewer resources to spend on public services, which should further be on a high level, i.e. in accordance with the preferences of its citizens (Hansson \& Olofsdotter, 2003). If tax systems between countries differ significantly, companies and individuals will for the 
place of capital investment and performing business activities choose the country where the total tax burden is lower. By shifting taxpayers to those countries where the tax burden is lower, automatically reduces tax revenues in countries that have a higher tax burden, causing difficult financing of public expenditures (Domazet \& Marjanović, 2018). An economy is competitive if it does things that are likely to encourage economic growth (Makrevska \& Nenovski, 2014). Observing the conditions where there is no competition, there are market conditions where there are little or insufficient bidders on the supply side who have the ability to determine market conditions, define prices as well as other factors which are in their favor, and not for individuals or companies (Marjanović et al., 2013; Round, 2009).

To the extent that economic integration between countries is gaining momentum, companies and individuals gain greater freedom to take advantage of the different economic opportunities offered to them, so their decision on capital investment, among others, is influenced by the tax factor. From the point of view of economic competition, the participants themselves take the initiative in seeking to realize their own interests and take a more favorable position in the global market, with the decisive role have market laws that determine the movement of supply and demand. In tax competition, however, the situation is different. She is caused by pressure from countries with low tax burdens, and other countries have to keep their tax pressures at a "reasonable" level, to discourage investors and workers from moving their business activities into such favorable tax environment (Kalamov, 2013; Siedschlag et al., 2013). Modern technologies are the bearers of global development, but also a priority for each country whose goal is to attract as many foreign investments as possible. The motive for broad tax incentives granted to an investor who brings high technology to the country is that high technology is the highest level of production modernization. By improving the production processes using modern technologies, it contributes to the competitiveness on the world market and hence the dynamic struggle for achieving tax attractiveness for investors who are high technology carriers. (Patterson \& Serrano, 1998) In the process of attracting foreign direct investment, it is necessary to take measures of tax policy ensuring that greater competition in the capital market. This is precisely the reason why the taxation systems introduced many changes, especially from the standpoint of tax incentives, exemptions and deductions (Domazet \& Marjanović, 2018). The investment incentives are highly effective in attracting foreign investments. However it is necessary to note, that to give the investor tax holidays is nowadays not enough. The country has to have a well-developed system, which will help the investor to realise his project within the investment scheme fast and without additional administrative costs (Porter, 2003).

\section{RESEARCH METHODOLOGY}

For the purposes of this empirical research, a quantitative approach has been used, which is based on the collection of numerical data, their mutual comparison, and the identification and analysis of the interrelationships between them. On the one hand, it was necessary for the sample to be representative, and on the other hand, through adequate approach and implementation of the research, qualitative and quantitative data were obtained on the basis of which it was possible to make certain conclusions. Therefore, this survey covered the 300 largest foreign investors that have invested capital in Serbia over the last 15 years. Considering that 88 investors took part in the survey, the response rate of $29.33 \%$ is considered to be quite satisfactory for all the criteria for this kind of research.

In order to determine the impact of tax incentives on foreign investors when choosing Serbia as an investment destination, a quantitative approach was applied in the survey using the method of testing, or survey technique via e-mail. This technique has been selected from the perspective of the quality and quantity of data that can be obtained by eliminating every form of bias of the person performing the research, as well as the benefits of this type of survey research for testing the selected target group. Therefore, the questions were of a closed type, since in this way it was 
possible to get more detailed and clearer answers, which can be coded and analyzed at a later stage. The research involved exclusively owners of companies, general directors or managers who are in charge of investments or operations in foreign markets.

Depending on the way of entry foreign investor to the market of Serbia, this research shows the importance of tax incentives in certain areas for the business of foreign investors in Serbia. Basic characteristics of the company who participated in the research are shown using schedule frequencies and percentages.

Table 1. Mode of entry foreign investors on the market of Serbia

\begin{tabular}{|c|c|c|c|}
\hline \multicolumn{2}{|c|}{ Direct investment } & \multicolumn{2}{c|}{ Indirect investment } \\
\hline Frequency & Percentage & Frequency & Percentage \\
\hline 47 & 53,4 & 41 & 46,6 \\
\hline
\end{tabular}

Source: authors`calculations

The first segment of the research was related to graphic presentation of all dependent variables and descriptive statistics, given that they made it possible visual presentation of results and calculation of frequencies, percentages, average estimates, standard deviation and variance. In the second segment, attention is focused on the analysis of differences in dependent variables, based on the subgroup of independent variables. More precisely, it was necessary to link the dependent and independent variables, since in this way it was possible to determine whether there were statistically significant differences in the evaluation of the investigated issues among different groups of foreign investors (the difference between three and more groups of respondents). For that purpose a single-factor analysis of the variance of different groups was used. (1)

$$
\begin{gathered}
\eta^{2}=\frac{\sum_{i=1}^{k} N_{i}\left(\overline{X_{i}}-\bar{X}\right)^{2}}{\sum_{i=1}^{k} \sum_{j=1}^{N_{j}}\left(X_{i j}-\bar{X}\right)^{2}} \\
\eta^{2}=\frac{\mathrm{t} 2}{\mathrm{t} 2+(\mathrm{N} 1+\mathrm{N} 2-2)}
\end{gathered}
$$

In a situation where it is necessary to compare the differences between two groups of respondents, for calculate the value statistically significant differences It was used t-test of independent samples. (2)

\section{RESEARCH RESULTS}

The results that have been achieved through the conducted empirical research, which were supposed to give an answer on the significance of tax incentives in certain areas for the business of foreign investors, first shown graphic, and after that through descriptive statistics and analyzes the differences between foreign investors depending on their individual characteristics in evaluation the significance of tax incentives in certain areas.

In order to determine the competitiveness of Serbian economy through the prism of tax incentives for foreign investors, the focus in empirical research was related to the establishment of the importance of tax incentives in certain areas for the business of foreign investors in Serbia, and depending on the way foreign investors entered the Serbian market. Consequently, attention 
is focused on tax incentives for investing in underdeveloped regions, tax incentives for investing in certain branches of industry, tax incentives for exporting companies, tax incentives for doing business in free zones, tax incentives for hiring new workers, tax incentives for the establishment of small and medium enterprises, tax incentives in corporate income tax and tax incentives for citizens' income tax.

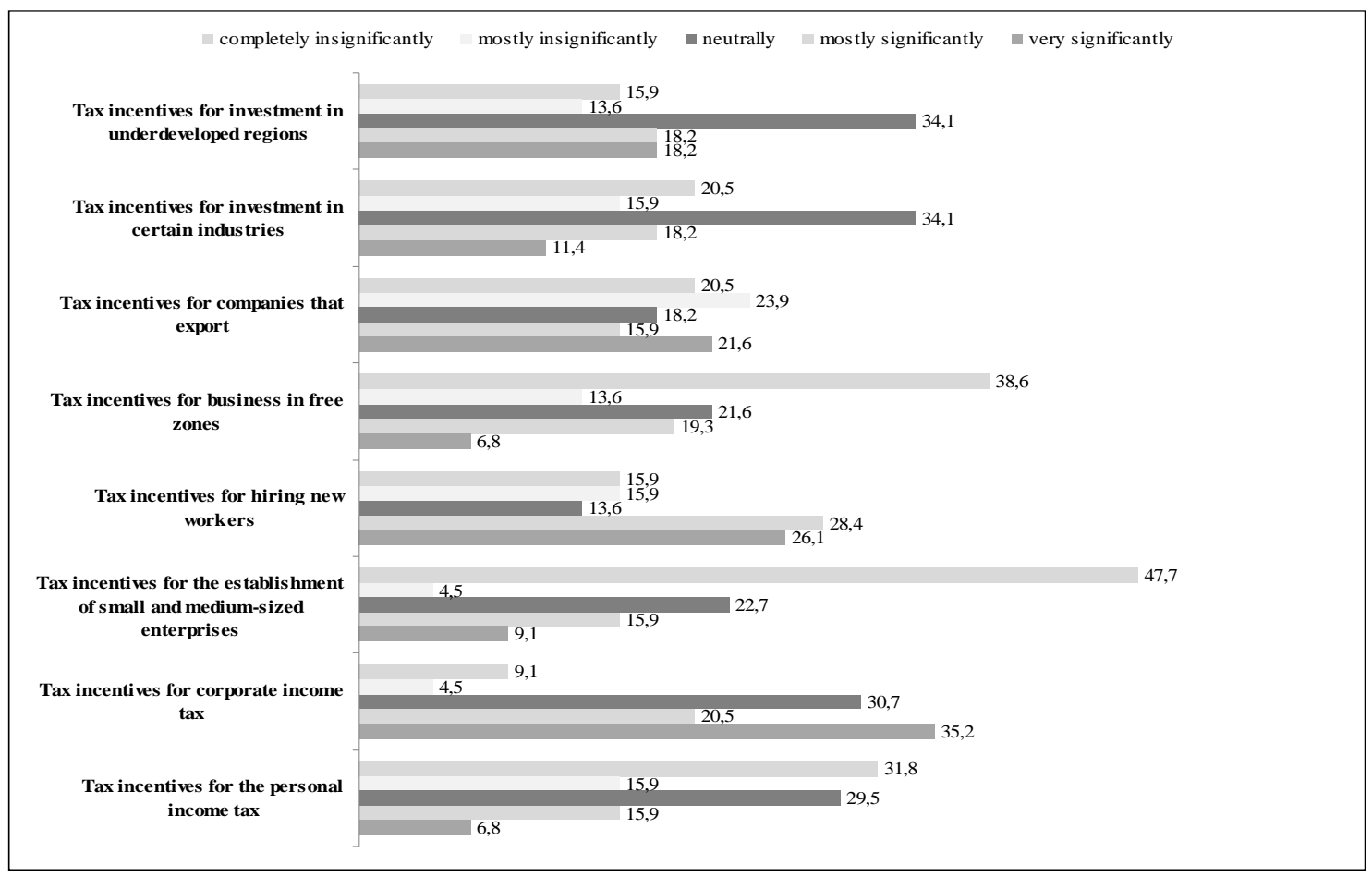

Figure 1. The importance of tax incentives in business activities of foreign investors in Serbia

Source: authors' calculations

According to the conducted survey, the largest number of foreign investors marked tax incentives in corporate income tax $(35.2 \%)$ as the most significant and determining factor for investment and business in Serbia. After that, tax incentives for recruitment of new workers (26.1\%), tax incentives for exporting enterprises (21.6\%), tax incentives for investing in underdeveloped regions (18.2\%), tax incentives for investing in certain (11.4\%), tax incentives for the establishment of small and medium enterprises (9.1\%), tax incentives for personal income $\operatorname{tax}(6.8 \%)$ and tax incentives for business in free zones $(6.8 \%)$.

After the graphic presentation, the descriptive statistics (Table 2) show the views of foreign investors, ie how the investors assessed the impact of tax incentives in certain areas on their business in Serbia. 
Table 2. The importance of tax incentives in business activities of foreign investors in Serbia

\begin{tabular}{|c|c|c|c|c|c|c|c|c|}
\hline & \multicolumn{5}{|c|}{ Degree of evaluation } & \multirow{3}{*}{$M$} & \multirow{3}{*}{$S D$} & \multirow{3}{*}{$\boldsymbol{V}$} \\
\hline & 1 & 2 & 3 & 4 & 5 & & & \\
\hline & $f(\%)$ & $f(\%)$ & $f(\%)$ & $f(\%)$ & $f(\%)$ & & & \\
\hline $\begin{array}{l}\text { Tax incentives for investments in } \\
\text { not sufficiently developed } \\
\text { regions }\end{array}$ & $\begin{array}{r}14 \\
(15,9)\end{array}$ & $\begin{array}{r}12 \\
(13,6)\end{array}$ & $\begin{array}{r}30 \\
(34,1)\end{array}$ & $\begin{array}{r}16 \\
(18,2)\end{array}$ & $\begin{array}{r}16 \\
(18,2)\end{array}$ & 3,0909 & 1,30107 & 1,693 \\
\hline $\begin{array}{l}\text { Tax incentives for investments in } \\
\text { certain industry branches }\end{array}$ & $\begin{array}{r}18 \\
(20,5) \\
\end{array}$ & $\begin{array}{r}14 \\
(15,9) \\
\end{array}$ & $\begin{array}{r}30 \\
(34,1) \\
\end{array}$ & $\begin{array}{r}16 \\
(18,2) \\
\end{array}$ & $\begin{array}{r}10 \\
(11,4) \\
\end{array}$ & 2,8409 & 1,26751 & 1,607 \\
\hline $\begin{array}{l}\text { Tax incentives for exporting } \\
\text { companies }\end{array}$ & $\begin{array}{r}18 \\
(20,5)\end{array}$ & $\begin{array}{r}21 \\
(23,9)\end{array}$ & $\begin{array}{r}16 \\
(18,2)\end{array}$ & $\begin{array}{r}14 \\
(15,9)\end{array}$ & $\begin{array}{r}19 \\
(21,6)\end{array}$ & 2,9432 & 1,44920 & 2,100 \\
\hline $\begin{array}{l}\text { Tax incentives for doing business } \\
\text { in free zones }\end{array}$ & $\begin{array}{r}34 \\
(38,6) \\
\end{array}$ & $\begin{array}{r}12 \\
(13,6)\end{array}$ & $\begin{array}{r}19 \\
(21,6) \\
\end{array}$ & $\begin{array}{r}17 \\
(19,3) \\
\end{array}$ & $\begin{array}{r}6 \\
(6,8) \\
\end{array}$ & 2,4205 & 1,35377 & 1,833 \\
\hline $\begin{array}{l}\text { Tax incentives for the } \\
\text { employment of new employees }\end{array}$ & $\begin{array}{r}14 \\
(15,9)\end{array}$ & $\begin{array}{r}14 \\
(15,9)\end{array}$ & $\begin{array}{r}12 \\
(13,6)\end{array}$ & $\begin{array}{r}25 \\
(28,4)\end{array}$ & $\begin{array}{r}23 \\
(26,1)\end{array}$ & 3,3295 & 1,42814 & 2,040 \\
\hline $\begin{array}{l}\text { Tax incentives for setting up } \\
\text { small and medium-sized } \\
\text { enterprises }\end{array}$ & $\begin{array}{r}42 \\
(47,7)\end{array}$ & $\begin{array}{r}4 \\
(4,5)\end{array}$ & $\begin{array}{r}20 \\
(22,7)\end{array}$ & $\begin{array}{r}14 \\
(15,9)\end{array}$ & $\begin{array}{r}8 \\
(9,1)\end{array}$ & 2,3409 & 1,43748 & 2,066 \\
\hline $\begin{array}{l}\text { Tax incentives in paying } \\
\text { corporate income taxes }\end{array}$ & $\begin{array}{r}8 \\
(9,1) \\
\end{array}$ & $\begin{array}{r}4 \\
(4,5) \\
\end{array}$ & $\begin{array}{r}27 \\
(30,7) \\
\end{array}$ & $\begin{array}{r}18 \\
(20,5) \\
\end{array}$ & $\begin{array}{r}31 \\
(35,2) \\
\end{array}$ & 3,6818 & 1,25529 & 1,576 \\
\hline $\begin{array}{l}\text { Tax incentives in paying income } \\
\text { tax by citizens }\end{array}$ & $\begin{array}{r}28 \\
(31,8) \\
\end{array}$ & $\begin{array}{r}14 \\
(15,9) \\
\end{array}$ & $\begin{array}{r}26 \\
(29,5) \\
\end{array}$ & $\begin{array}{r}14 \\
(15,9)\end{array}$ & $\begin{array}{r}6 \\
(6,8) \\
\end{array}$ & 2,5000 & 1,27757 & 1,632 \\
\hline
\end{tabular}

Source: authors`calculations

The existence of statistically significant differences between foreign investors in assessing the significance of tax incentives in certain areas for the business of foreign investors in Serbia was investigated through the t-test of independent samples.

The results of the t-test of independent samples on the existence of statistically significant differences between foreign investors entering the Serbian market through direct investment and foreign investors entering the market of Serbia through an indirect investment in assessing the significance of tax incentives in certain areas are shown in Table 3.

Table 3. Differences between foreign investors in evaluation the degree of significance of tax incentives in certain areas, and depending on the mode of entry to the market of Serbia

\begin{tabular}{|c|c|c|c|c|c|c|c|}
\hline & \multicolumn{2}{|c|}{$\begin{array}{c}\text { M } \\
\text { (SD) }\end{array}$} & \multirow{2}{*}{ MD } & \multicolumn{2}{|c|}{$\begin{array}{l}95 \% \\
\text { CID }\end{array}$} & \multirow{2}{*}{ t } & \multirow{2}{*}{$\mathbf{p}^{*}$} \\
\hline & $\begin{array}{c}\text { DI, } \\
\mathrm{N}=47\end{array}$ & $\begin{array}{c}\text { II, } \\
N=41\end{array}$ & & Lower & Upper & & \\
\hline $\begin{array}{l}\text { Tax incentives for investments in not } \\
\text { sufficiently developed regions }\end{array}$ & $\begin{array}{r}3,5106 \\
(1,17718)\end{array}$ & $\begin{array}{r}2,6098 \\
(1,28215)\end{array}$ & 0,90088 & 0,37958 & 1,42218 & 3,435 & 0,001 \\
\hline $\begin{array}{l}\text { Tax incentives for investments in } \\
\text { certain industry branches }\end{array}$ & $\begin{array}{r}2,9362 \\
(1,35782) \\
\end{array}$ & $\begin{array}{r}2,7317 \\
(1,16242) \\
\end{array}$ & 0,20446 & $-0,33534$ & 0,74427 & 0,753 & 0,454 \\
\hline $\begin{array}{l}\text { Tax incentives for exporting } \\
\text { companies }\end{array}$ & $\begin{array}{r}3,1064 \\
(1,41781)\end{array}$ & $\begin{array}{r}2,7561 \\
(1,47954)\end{array}$ & 0,35029 & $-0,26436$ & 0,96493 & 1,133 & 0,260 \\
\hline $\begin{array}{l}\text { Tax incentives for doing business in } \\
\text { free zones }\end{array}$ & $\begin{array}{r}2,7021 \\
(1,36597) \\
\end{array}$ & $\begin{array}{r}2,0976 \\
(1,28072) \\
\end{array}$ & 0,60457 & 0,04083 & 1,16830 & 2,132 & 0,036 \\
\hline $\begin{array}{l}\text { Tax incentives for the employment of } \\
\text { new employees }\end{array}$ & $\begin{array}{r}3,4681 \\
(1,41192) \\
\end{array}$ & $\begin{array}{r}3,1707 \\
(1,44745) \\
\end{array}$ & 0,29735 & $-0,30952$ & 0,90423 & 0,974 & 0,333 \\
\hline \begin{tabular}{|l|} 
Tax incentives for setting up small \\
and medium-sized enterprises
\end{tabular} & $\begin{array}{r}2,8298 \\
(1,46435) \\
\end{array}$ & $\begin{array}{r}1,7805 \\
(1,19399) \\
\end{array}$ & 1,04930 & 0,47776 & 1,62084 & 3,650 & 0,000 \\
\hline \begin{tabular}{|l|} 
Tax incentives in paying corporate \\
income taxes
\end{tabular} & $\begin{array}{r}3,5957 \\
(1,32959)\end{array}$ & $\begin{array}{r}3,7805 \\
(1,17286)\end{array}$ & $-0,18474$ & $-0,71964$ & 0,35015 & $-0,687$ & 0,494 \\
\hline $\begin{array}{l}\text { Tax incentives in paying income tax } \\
\text { by citizens }\end{array}$ & $\begin{array}{r}2,9149 \\
(1,29933)\end{array}$ & $\begin{array}{r}2,0244 \\
(1,08369)\end{array}$ & 0,25726 & 0,37909 & 1,40192 & 3,461 & 0,001 \\
\hline
\end{tabular}

* statistically significant difference occurs at the level $\mathrm{p}<0,05$

Source: authors 'calculations 
The results of the t-test of independent samples showed that there are the following statistically significant differences between foreign investors:

In assessing the impact of tax incentives for investing in underdeveloped regions, $t(86)=3,435$, $p=0,001, M D=0,90088,95 \%$ CID: from 0,37958 to 1,42218 between foreign investors who entered the Serbian market with a direct investment $(M=3,5106, S D=1,17718)$ and those who entered the Serbian market with an indirect investment $(M=2,6098, S D=1,28215)$. The size of the difference between these two groups of foreign investors expressed by the eta square is $\eta^{2}=$ 0,120 and can be considered as a big difference. Accordingly, foreign investors entering the Serbian market through direct investment have given greater importance to the impact of tax incentives for investing in underdeveloped regions compared to those entering the Serbian market through an indirect investment.

In assessing the impact of tax incentives for business in free zones, $t(86)=2,132, p=0,036, M D$ $=0,60457,95 \%$ CID: from 0,04083 to 1,16830 between foreign investors who entered the Serbian market with a direct investment $(M=2,7021, S D=1,36597)$ and those who entered the Serbian market with an indirect investment $(M=2,0976, S D=1,28072)$. The size of the difference between these two groups of foreign investors expressed by the eta square is $\eta^{2}=0,050$ and can be considered a small difference. Accordingly, foreign investors entering the Serbian market through direct investment have given greater importance to the impact of tax incentives for business in free zones in relation to those who entered the Serbian market through an indirect investment.

In assessing the impact of tax incentives for the establishment of small and medium-sized enterprises, $t(86)=3,650, p=0,000, M D=1,04930,95 \% C I D$ : from 0,47776 to 1,62084 between foreign investors who entered the Serbian market with a direct investment $(M=2,8298, S D=$ $1,46435)$ and those who entered the Serbian market with an indirect investment $(M=1,7805, S D$ $=1,19399$ ). The size of the difference between these two groups of foreign investors expressed by the eta square is $\eta^{2}=0,134$ and can be considered as a big difference. Accordingly, foreign investors entering the Serbian market through direct investment have given greater importance to the impact of tax incentives for the establishment of small and medium-sized enterprises in relation to those who entered the Serbian market through an indirect investment.

In assessing the impact of tax incentives on citizens' income tax, $t(86)=3,461, p=0,001, M D=$ 0,25726, 95\% CID: from 0,37909 to 1,40192 between foreign investors who entered the Serbian market with a direct investment $(M=2,9149, S D=1,29933)$ and those who entered the Serbian market with an indirect investment $(M=2,0244, S D=1,08369)$. The size of the difference between these two groups of foreign investors expressed by the eta square is $\eta^{2}=0,122$ and can be considered as a big difference. Accordingly, foreign investors entering the Serbian market through direct investment have given greater importance to the impact of tax incentives on citizens' income tax in relation to those who entered the Serbian market through an indirect investment.

\section{CONCLUSION}

The aim of this research is to identify potential problems that can negatively affect the decision of a foreign investor when investing capital in Serbia. That is, which are tax incentives and to what extent is significant for foreign investors, which in the coming period can contribute to the improvement of the business environment in Serbia. The results of the conducted research were clearly and unequivocally pointed out, that for foreign investors, tax incentives is very important, with special emphasis on tax incentives in corporate income tax. When it comes to these tax incentives, it is primarily thought to reduce tax rates, tax holidays or investment incentives. The very low rates of corporate income tax have a positive impact on investments, and therefore on the competitiveness of Serbia internationally. Multinational companies most closely match low tax rates, given that the main benefits relate to the simplicity and transparency of the cost of 
fulfilling the tax obligation, the generality, the horizontal character of the relief, and neutrality in relation to other tax incentives.

Given that foreign investors have certain expectations regarding the business environment in Serbia, it is more important that the significance of tax incentives be adequately pointed out in the next period. Therefore, it is extremely important that economic policy creators in Serbia in an adequate way executed implementation those tax incentives which foreign investors expressed through this research. If one looks at the obtained results, it is clear that in the coming period there are good prospects for increasing the inflow of foreign capital. Therefore, it is very important to investors to offer a broader spectrum of tax incentives, where special attention should be paid to those tax incentives which investors categorized as less important in this survey. Of course, in no case should be neglected other indicators that have a certain impact on investors when choosing Serbia as an investment destination. In this way it is possible to improve the business environment as a factor of competitiveness of the Serbian economy.

From all of the foregoing, it is clear that the results of this research are primarily intended for the creators of tax policy in Serbia. It is very important to spot the weakness of the tax system in time, and then implement the implementation of all requirements that are expressed through this research. In this way, a clear signal will be sent to investors that the Serbian economy is open to the inflow of fresh capital. Especially this will be expressed if new tax incentives is introduced with appropriate corrections of already existing tax incentives. If all necessary activities are carried out in the forthcoming period, primarily regarding the selection and implementation of adequate tax incentives, Serbia will come into position to be a leader in the region when it comes to competitiveness and, therefore, a very attractive investment destination.

\section{ACKNOWLEDGEMENTS}

This paper is a part of research projects numbers III47009 (European integrations and social and economic changes in Serbian economy on the way to the EU) and OI179015 (Challenges and prospects of structural changes in Serbia: Strategic directions for economic development and harmonization with EU requirements), financed by the Ministry of Science and Technological Development of the Republic of Serbia.

\section{REFERENCES}

Baskaran, Thushyanthan, Feld, Lars P., and Schnellenbach, Jan. 2016. "Fiscal federalism, decentralization, and economic growth: a meta-analysis". Economics Inquiry, 54 (3): 14451463.

Castro, Vitor. 2011. "The impact of the European Union fiscal rules on economic growth." Journal of Macroeconomics, 33: 313-326.

Chu, Angus, and Yang, C. 2012. "Fiscal centralization versus decentralization: Growth and welfare effects of spillovers, Leviathan taxation, and capital mobility." Journal of Urban Economics, 71: 177-188.

Collis, David, Young, David, and Goold, Michael. 2012. "The Size and Composition of Corporate Headquarters in Multinational Companies: Empirical Evidence." Journal of International Management, 18: 260-275.

Cooper, David J., and Ezzamel, Mahmoud. 2013. "Globalization discourses and performance measurement systems in a multinational firm." Accounting, Organizations and Society, 38: 288313.

Davies, Ronald B., and Voget, Johannes. 2008. "Tax Competition in an Expanding European Union." Oxford University Centre for Business Taxation Working Paper No. 08-03.

Domazet, Ivana, and Marjanović, Darko. 2018. "FDI as a Factor of Improving the Competitiveness of Developing Countries: FDI and Competitiveness." International Monograph: 
Foreign Direct Investments (FDIs) and Opportunities for Developing Economies in the World Market, ed. Venkataramanaiah Malepati, 82-104. Hershey: IGI Global.

Domazet, Ivana, and Marjanović, Darko. 2017. „Tax incentives as a factor of economic growth.” International Monograph: The state and the market in economic development: In Pursuit of millennium development goals, 93-107. Brisbane: The International Institute of Development Studies.

Domazet, Ivana, and Marjanović, Darko. 2016. "Improving the business environment in Serbia through tax incentives for foreign investors." Paper presented at the international scientific conference of the Institute of Economic Science, Belgrade.

Easson, Alex, and Eric Zolt M. 2003. "Tax Incentives." World Bank Institute, Washington D.C.

Eyraud, Luc, and Lusinyan, Lusine. 2013. "Vertical fiscal imbalances and fiscal performance in advanced economies." Journal of Monetary Economics, 60: 571-587.

Fernández-de-Córdoba, Gonzalo, and Torres, Jose L. 2012. "Fiscal harmonization in the European Union with public inputs." Economic Modelling, 29: 2024-2034.

Gurgul, Henryk, and Lach, Lukasz. 2014. "Globalization and economic growth: Evidence from two decades of transition in CEE." Economic Modelling, 36: 99-107.

Hansson, Åsa, and Olofsdotter Karin. 2003. „The effects of tax competition and new economic geography on taxation in OECD countries.", Department of Economics Lund University.

Harger, Kaitlyn, and Ross, Amanda. 2016. „Do capital tax incentives attract new businesses? Evidence across industries from the new markets tax credit." Journal of Regional Science, 56 (5): 733-753.

Hatfield, John W. 2015. „Federalism, taxation, and economic growth.“ Journal of Urban Economics, 87: 114-125.

Kalamov, Zarko Y. 2013. „Risk sharing and the efficiency of public good provision under tax competition." Regional Science and Urban Economics, 43: 676-683.

Keen, Michael, and Konrad Kai A. 2012. „International Tax Competition and Coordination.“ Max Planck Institute for Tax Law and Public Finance Working Paper 2012-06.

Li, Quan. 2016. "Fiscal decentralization and tax incentives in the developing world" Review of International Political Economy, 23: 232-260.

Makrevska, Elena D. and Nenovski, Tome. 2014. "Competitiveness of the European Union: Precrisis Trends and Impact of the Financial Crisis." Economic Analysis, 47(3-4): 20-34.

Marjanović, Darko, Dragaš, Radovan, and Radojević, Predrag. 2013. “Competitiveness In The Serbian Economy In The Period of Crisis.", EMC2013 - Zrenjanin, 323-328.

Marjanović, Darko, and Pjanić, Miloš. 2012. "The Effects Of Tax Competition On The Operations Of Multinational Companies." EMC2012 - Zrenjanin, 211-216.

McCarthy, Killian, Van Doorn, Frederik, and Unger, Brigit. 2008. "Globalisation, tax competition and the harmonisation of corporate tax rates in Europe: a case of killing the patient to Cure the disease." Utrecht School of Economics Discussion Paper Series 08-13.

Musabegović, Ismail, Galetin, Milena, and Mitić, Petar. 2015. "Foreign Direct Investments - the Standard of Fair and Equitable Treatment of Investments on the Example of a Case of the International Center for Settlement of Investment Disputes (ICSID)“. Economic Analysis, 48(12): 86-97.

Owens, Jeffrey. 2006. "Fundamental Tax Reform: An International Perspective." National Tax Journal, 59(1): 131-164.

Paraušić, Vesna, Domazet, Ivana, and Simeunović, Ivana. 2017. “Analysis of the Relationship Between the Stage of Economic Development and the State of Cluster Development." Argumenta Oeconomica, 39 (2): 279-305.

Patterson, Ben, and Serrano, Alicia M. 1998. “Tax competition in the Europen Union." European Parliament Working Paper ECON-105 EN.

Porter, Michael E. 2003. "The Economic Performance of Regions." Regional Studies, 37 (6\&7): 549-578. 
Radičić, Marko, and Raičević, Božidar. 2011. „Javne finansije u teoriji i praksi.“ Data status, Beograd.

Round, John. 2009. “Transitional Economies.” International Encyclopedia of Human Geography, 355-360.

Sedmihradsky, Milan, and Klazar, Stanislav. 2002. "Tax competition for FDI in CentralEuropean Countries", CESifo Working Paper Series No. 647.

Siedschlag, Iulia, Smith, Donal, Turcu, Camelia, and Zhang, Xiaoheng. 2013. "What determines the location choice of R\&D activities by multinational firms?." Research Policy, 42: $1420-1430$.

Tagkalakis, Athanasios. 2011. "Fiscal policy and financial market movements", Journal of Banking \& Finance, 35: 231-251.

Talpos, Ioan, and Crasneac, Alexandru 0. 2010. "The effects of tax competition." Theoretical and Applied Economics, XVII (8): 39-52.

Willis, Gavin. 2016. "Tax incentives and investment in the UK". Oxford Economics Paper, 68 (2): 465-483.

Zolt, Eric. 2015. "Tax Incentives: Protecting the tax base". Paper for Workshop on Tax Incentives and Base Protection, United Nations, New York.

\begin{tabular}{l|l} 
Article history: & Received: November 3, 2018 \\
\cline { 2 - 2 } & Accepted: December 20,2018 \\
\hline
\end{tabular}

Accepted: December 20, 2018 